\title{
LIMBAH BIOGAS KOTORAN AYAM SEBAGAI ALTERNATIF SUMBER PROTEIN PAKAN BENIH IKAN PATIN (Pangasianodon hypophthalmus)
}

\author{
Gleni Hasan Huwoyon ${ }^{1 *}$, Anik Martinah Hariati ${ }^{2}$ dan Rudhy Gustiano ${ }^{1}$ \\ ${ }^{1}$ Balai Riset Perikanan Budidaya Air Tawar, Jl. Sempur No. 1, Bogor. \\ *e-mail : gleni_hh@yahoo.com \\ ${ }^{2}$ Program Studi Budidaya Perairan, Fakultas Perikanan, \\ Universitas Brawijaya, Malang
}

\author{
ABSTRACT \\ Chicken Manure Biogas Waste as Protein Source for Patin FryF. \\ By. Gleni Hasan Huwoyon, Anik Martinah Hariati and Rudhy Gustiano
}

\begin{abstract}
The hight of production cost encourage to search for alternative low price feed. The objectives of the study was to know an appropriate substitution by chicken manure biogas protein for soybean meal protein, and the influence on growth performance and feed efficiency of siames catfish (Pangasianodon hypophthalmus). The treatments of chicken manure biogas protein consisted of control $(A=0 \%)$ and four treatment $(B=8 \%, C=$ $16 \%, D=24 \%$ dan $E=32 \%)$. The results showed that best chicken manure biogas protein was found in treatments $C(16 \%)$, with survival rate of $100 \%$, specific growth rate $(3,4 \% \mathrm{bw} /$ day), feed conversion ratio $(1,0)$, retention of energy (30,3\%), protein efficiency ratio $(3,6 \mathrm{~g} / \mathrm{g})$ and $47,8 \%$ of protein retention. Conclusion showed that the chicken manure biogas protein could be used to substitute for soybean meal with the best result in treatment of feed $\mathrm{C}=16 \%$.
\end{abstract}

Keywords : biogas waste, chicken manure, feed, siames catfish, pangasianodon hypophthalmus

\begin{abstract}
ABSTRAK
Tingginya biaya produksi yang menyebabkan mencari alternatif agar pakan murah. Penelitian ini bertujuan untuk mencari substitusi yang tepat antara protein limbah biogas kotoran ayam terhadap protein bungkil kedelai, serta pengaruhnya terhadap pertumbuhan dan perbandingan efisiensi pakan benih ikan patin (Pangasianodon hypophthalmus). Perlakuan pakan substitusi protein limbah biogas kotoran ayam terhadap protein bungkil kedelai terdiri atas kontrol $(\mathrm{A}=0 \%)$ dan 4 perlakuan $(\mathrm{B}=8 \%, \mathrm{C}=16 \%, \mathrm{D}=24 \%$ dan $\mathrm{E}=$ $32 \%$ ). Hasil penelitian menunjukan bahwa substitusi terbaik pada protein limbah biogas kotoran ayam terhadap protein bungkil kedelai didapatkan pada perlakuan pakan $\mathrm{C}=16 \%$, dengan nilai sintasan $100 \%$, laju pertumbuhan spesifik 3,4 \% bt/hari, rasio konversi pakan 1,0, retensi energi 30,3\%, rasio efisiensi protein 3,6 g/g dan retensi protein $47,8 \%$. Dari data dapat ditarik kesimpulan bahwa limbah biogas kotoran ayam dapat dimanfaatkan sebagai substitusi bungkil kedelai dengan hasil terbaik pada perlakuan pakan $\mathrm{C}=16 \%$.
\end{abstract}

Kata kunci : limbah biogas, kotoran ayam, pakan, patin, pangasianodon hypophthalmus

\section{PENDAHULUAN}

Seiring dengan meningkatnya jumlah penduduk, daya konsumsi masyarakat terhadap ikan khususnya ikan patin juga mengalami peningkatan. Gustiano (2003) melaporkan bahwa terdapat 14 spesies dari famili Pangasiidae di Indonesia, termasuk didalamnya jenis Pangasianodon hypophthalmus yang berasal dari Thailand. Di antara berbagai spesies ikan air tawar yang potensial untuk dibudidayakan secara komersial, ikan patin menempati posisi tersendiri terutama untuk konsumen di Sumatera dan Kalimantan (Nasution et al., 1997; Asyari et al., 1997; Ahmad et al., 2007).

Dalam usaha budidaya, faktor penentu yang perlu diperhatikan adalah pakan. Pemilihan bahan baku pakan yang baik dan bermutu tinggi perlu memperhatikan nilai gizinya, kemudahan dalam memperoleh bahan baku, mudah dalam pengolahan, mudah dicerna, harga 
murah dan tidak mengandung bahan beracun (Hariati, 1989).

Dikaitkan dengan keadaan perekonomian yang sedang melanda negara kita, maka dalam penyediaan produk pakan bermutu tinggi perlu memperhitungkan nilai ekonomisnya. Menurut Tahapari et al., (2007) pengaruh jumlah pemberian pakan buatan terhadap benih ikan patin perlu dilakukan untuk menunjang keberhasilan dalam pembesaran benih ikan patin. Utami et al., (2003) juga telah mempelajari tentang jenis dan jumlah pakan alami yang diberikan untuk memenuhi kebutuhan protein pada benih ikan patin. Suhenda et al., (2006) melaporkan bahwa benih ikan patin dapat dipelihara dalam lingkungan yang terkontrol dan sangat responsif terhadap pakan buatan yang diberikan.

Salah satu cara untuk mengatasi tingginya biaya produksi pakan adalah dengan melakukan suatu penelitian untuk mencari sumber bahan pakan yang baru sebagai alternatif bahan pengganti pakan yang biasa digunakan. Yunus (1995) mengatakan bahwa dalam dunia peternakan, kotoran ternak dituduh sebagai sumber polusi dan pencemaran lingkungan. Kondisi tersebut kemudian mendorong munculnya pemikiran untuk memanfaatkan kotoran ternak untuk diolah menjadi biogas. Hasil sampingan dari biogas adalah limbah biogas yang dapat digunakan sebagai bahan campuran pakan ikan. Selain lebih ekonomis, limbah biogas lebih menguntungkan bila dijadikan sebagai pakan ternak maupun ikan karena nilai gizi yang terkandung didalamnya.

Tujuan penelitian ini untuk mencari substitusi yang tepat antara protein limbah biogas kotoran ayam terhadap protein bungkil kedelai, serta pengaruhnya terhadap pertumbuhan dan perbandingan efisiensi pakan benih ikan patin (Pangasianodon hypophthalmus).

\section{BAHAN DAN METODE}

Ikan uji yang digunakan adalah benih ikan patin berukuran $3-5 \mathrm{~cm}$ dengan berat rata - rata 0,81 gram sebanyak 45 ekor/akuarium yang diberi aerasi dengan volume 40 liter air. Bahan pakan yang digunakan adalah limbah biogas kotoran ayam. Analisa proksimat limbah biogas kotoran ayam dan tepung bungkil kedelai dapat dilihat pada Tabel 1 .

Formula pakan terdiri dari lima macam pakan yang mengandung substitusi protein limbah biogas kotoran ayam terhadap protein bungkil kedelai dari $0-32 \%$. Formulasi pakan benih ikan patin dapat dilihat pada Tabel 2. Persiapan penelitian meliputi penentuan formulasi pakan, pembuatan pakan dan analisa proksimat pakan uji. Analisa proksimat pakan dilihat pada Tabel 3 .

Tabel 1. Analisa Proksimat Limbah Biogas dan Tepung Bungkil Kedelai

\begin{tabular}{lcc}
\hline \multicolumn{1}{r}{ Komposisi } & Limbah Biogas & Tepung Bungkil Kedelai \\
\hline Bahan Kering (\%) & 94,36 & 87,69 \\
Abu (\%) & 64,40 & 6,85 \\
Protein Kasar (\%) & 15,72 & 47,75 \\
Serat Kasar (\%) & 14,86 & 6,21 \\
Lemak Kasar (\%) & 0,62 & 1,10 \\
BETN (\%) & 4,40 & 38,09 \\
ME (kkal/g) & 2,13 & 3,77 \\
\hline
\end{tabular}


Tabel 2. Formulasi Pakan Benih Ikan Patin

\begin{tabular}{lccccc}
\hline \multirow{2}{*}{ Bahan } & \multicolumn{5}{c}{ Perlakuan } \\
\cline { 2 - 6 } & $0 \%$ & $8 \%$ & $16 \%$ & $24 \%$ & $32 \%$ \\
\hline Tepung Ikan & 33 & 33,78 & 34,3 & 34,8 & 35,36 \\
Tepung Bungkil Kedelai & 20 & 18,4 & 16,8 & 15,2 & 13,6 \\
Limbah Biogas Kotoran Ayam & 0 & 4,68 & 9,72 & 14,58 & 19,44 \\
Tepung Jagung & 10 & 10 & 10 & 10 & 10 \\
Tepung Tapioka & 10 & 10 & 10 & 10 & 10 \\
Dedak & 24,5 & 20,64 & 16,68 & 12,92 & 9,1 \\
Cr $\mathrm{O}_{3}$ & 0,5 & 0,5 & 0,5 & 0,5 & 0,5 \\
Top Mix & 2 & 2 & 2 & 2 & 2 \\
Total & 100 & 100 & 100 & 100 & 100 \\
\hline
\end{tabular}

Tabel 3. Analisa Proksimat Pakan Uji Benih Ikan Patin

\begin{tabular}{lccccc}
\hline \multirow{2}{*}{ Bahan } & \multicolumn{5}{c}{ Perlakuan } \\
\cline { 2 - 6 } & $0 \%$ & $8 \%$ & $16 \%$ & $24 \%$ & $32 \%$ \\
\hline Protein (g) & 27,43 & 27,93 & 27,12 & 27,03 & 27,83 \\
Lemak (\%) & 8,11 & 7,85 & 8,08 & 7,82 & 5,36 \\
Berat Kering (\%) & 84,61 & 89,18 & 80,05 & 88,45 & 90,77 \\
Abu (\%) & 11,52 & 13,14 & 16,88 & 19,08 & 25,07 \\
Karbohidrat (\%) & 52,65 & 51,13 & 47,92 & 45,81 & 41,85 \\
Energi (\%) & 3,71 & 3,95 & 3,72 & 3,11 & 3,37 \\
\hline
\end{tabular}

Pelaksanaan penelitian meliputi analisa proksimat ikan pada awal penelitian, penimbangan awal dan pemeliharaan ikan uji. Pemberian pakan 5 $\%$ bobot tubuh/hari, diberikan sebanyak 3 kali. Ikan ditimbang seminggu sekali untuk mengetahui laju pertumbuhan ikan, serta dilakukan pengukuran kualitas air. Pada akhir penelitian ikan ditimbang dan dianalisa proksimat serta dilakukan perhitungan data yang meliputi :
- $\quad$ Sintasan

$$
\begin{aligned}
& \mathrm{SR}=\frac{\mathrm{Nt}}{\mathrm{No}} \times 100 \% \\
& \mathrm{SR}: \begin{array}{l}
\text { Sintasan (\%) } \\
\mathrm{Nt}
\end{array} \\
& \mathrm{No} \quad \begin{array}{l}
\text { Jumlah ikan pada akhir } \\
\text { penelitian (ekor) }
\end{array} \\
& \mathrm{Numlah} \text { ikan pada awal } \\
& \text { penelitian (ekor) }
\end{aligned}
$$


- Laju Pertumbuhan Spesifik (Castell \& Tiews, 1980)

$$
\mathrm{SGR}=\frac{(\ln \mathrm{Wt}-\ln \mathrm{Wo})}{\mathrm{t}} \times 100 \%
$$

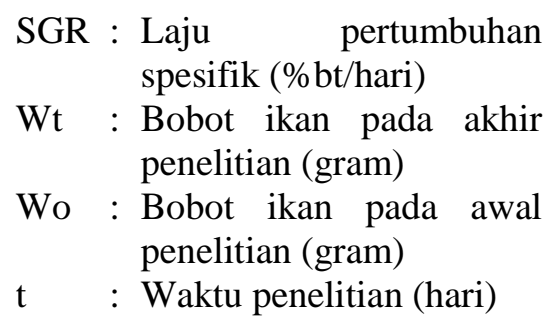

- Rasio Konversi Pakan (Hariati, 1989)

$$
\mathrm{FCR}=\frac{\mathrm{F}}{\mathrm{Wt}-\mathrm{Wo}_{\mathrm{O}}} \times 100 \%
$$

FCR : Rasio konversi pakan

F : Jumlah pakan yang diberikan (gram)

Wt : Bobot ikan pada akhir penelitian (gram)

Wo : Bobot ikan pada awal penelitian (gram)

- $\quad$ Retensi Energi (Hariati, 1989)

$$
\mathrm{RE}=\frac{((\mathrm{Wt} \times \mathrm{Et})-(\mathrm{Wo} \times \mathrm{Eo}))}{\mathrm{F} \times \mathrm{Ef}} \times 100 \%
$$

RE : Retensi energi (\%)

Et : Energi ikan pada akhir penelitian (kkal/gram)

Eo : Energi ikan pada awal penelitian (kkal/gram)

Ef : Energi pakan (kkal/gram)

Wt : Bobot ikan pada akhir penelitian (gram)
Wo : Bobot ikan pada awal penelitian (gram)

Rasio Efisiensi Protein (Castell \& Tiews, 1980)

$$
\begin{aligned}
& \mathrm{REP}=\frac{\mathrm{Wt}-\mathrm{Wo}}{\mathrm{F} \times \mathrm{Pf}} \times 100 \% \\
& \mathrm{REP}: \text { Rasio efisiensi protein } \\
& \text { (gram/gram) } \\
& \mathrm{Pf} \quad: \text { Protein pakan (gram) } \\
& \mathrm{Wt} \quad \text { Bobot ikan pada akhir } \\
& \text { penelitian (gram) } \\
& \mathrm{Wo} \quad \begin{array}{l}
\text { Bobot ikan pada awal } \\
\text { penelitian (gram) }
\end{array}
\end{aligned}
$$

- Retensi Protein (Viola \& Rappaport, 1979)

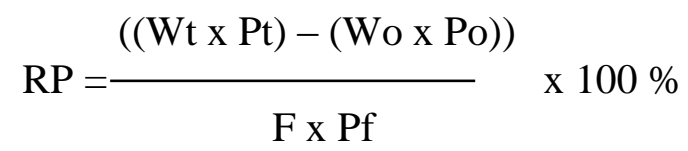

RP : Retensi protein (\%)

Pt : Protein ikan pada akhir penelitian (gram)

Po : Protein ikan pada awal penelitian (gram)

Wt : Bobot ikan pada akhir penelitian (gram)

Wo : Bobot ikan pada awal penelitian (gram)

Rancangan menggunakan Rancangan Acak Lengkap (RAL) dengan 4 perlakuan $(\mathrm{B}=8 \%, \mathrm{C}=16 \%, \mathrm{D}=24 \%$ dan $\mathrm{E}=32 \%)$ serta kontrol $(\mathrm{A}=0 \%)$ dan diulang sebanyak 3 kali.

\section{HASIL DAN PEMBAHASAN}

Benih ikan patin yang dipelihara selama 28 hari menghasilkan sintasan sebesar $100 \%$ untuk semua perlakuan. Sintasan yang tinggi disebabkan karena pakan yang diberikan sesuai dengan 
kebutuhan benih, yaitu pakan sudah tidak mengandung amoniak karena sudah melalui proses biogas, selain itu kepadatan untuk tiap akuarium rendah dan kualitas air berada pada kondisi optimal. Bondari (1984), mengatakan bahwa lingkungan tempat pemeliharaan ikan akan mempengaruhi laju pertumbuhan dan sintasan dan dengan kemampuan beradaptasi yang baik akan mempunyai kemampuan tumbuh yang baik. Data hasil penelitian dapat dilihat pada Tabel 4 .

Tabel 4. Data Hasil Penelitian

\begin{tabular}{lccccc}
\hline \multirow{2}{*}{ Parameter Utama } & \multicolumn{5}{c}{ Perlakuan } \\
\cline { 2 - 6 } & $0 \%$ & $8 \%$ & $16 \%$ & $24 \%$ & $32 \%$ \\
\hline $\begin{array}{l}\text { Laju Pertumbuhan Spesifik } \\
\text { (\%bt/hari) }\end{array}$ & $3,4 \pm 0,01^{\text {a }}$ & $3,4 \pm 0,01^{\text {a }}$ & $3,4 \pm 0,02^{\text {a }}$ & $3,4 \pm 0,01^{\text {a }}$ & $3,4 \pm 001^{\text {a }}$ \\
Rasio Konversi Pakan & $1,1 \pm 0,02^{\text {a }}$ & $1,1 \pm 0,02^{\text {a }}$ & $1,0 \pm 0,02^{\text {b }}$ & $1,1 \pm 0,02^{\text {a }}$ & $1,1 \pm 0,02^{\text {a }}$ \\
Retensi Energi (\%) & $26,9 \pm 0,80^{\text {a }}$ & $28,6 \pm 0,60^{\text {ab }}$ & $30,3 \pm 2,09^{\text {b }}$ & $28,9 \pm 0,92^{\text {ab }}$ & $28,4 \pm 1,10^{\text {ab }}$ \\
Rasio Efisiensi Protein (g/g) & $3,4 \pm 0,08^{\text {a }}$ & $3,4 \pm 0,08^{\text {a }}$ & $3,6 \pm 0,09^{\text {a }}$ & $3,5 \pm 0,07^{\text {a }}$ & $3,4 \pm 0,07^{\text {a }}$ \\
& & & & & \\
Retensi Protein (\%) & $45,8 \pm 1,13^{\text {a }}$ & $46,1 \pm 0,96^{\text {a }}$ & $47,8 \pm 1,13^{\text {a }}$ & $47,6 \pm 0,90^{\text {a }}$ & $45,8 \pm 0,83^{\text {a }}$
\end{tabular}

Notasi huruf di atas menunjukan perbedaan antar perlakuan

Benih ikan patin yang telah dipelihara selama 28 hari menghasilkan laju pertumbuhan spesifik yang tidak berbeda nyata pada semua perlakuan pakan. Khans (1993) ; Kadarini (2004) mengatakan bahwa protein merupakan salah satu nutrien penting yang dibutuhkan untuk pertumbuhan. Yunus (1995) mengemukakan bahwa penggunaan limbah biogas sebagai hasil samping proses fermentasi kotoran ternak cukup lengkap sebagai sumber nutrien bagi ikan ataupun ternak.

Hasil rata-rata rasio konversi pakan terbaik didapatkan pada perlakuan C (16\%) sebesar 1,0 $\pm 0,02$, berbeda nyata $(\mathrm{P}<0,05)$ dengan perlakuan $\mathrm{A}$ $(0 \%), \mathrm{B}(8 \%), \mathrm{D}(24 \%)$ dan E (32\%) sebesar 1,1 $\pm 0,02$, hal ini sesuai dengan pernyataan Ekawati (1992) bahwa efisiensi pakan sangat dipengaruhi oleh kadar energi dalam pakan. Kadar energi pakan yang rendah akan menunjukan efisiensi pakan yang rendah pula. Rasio konversi pakan pada benih ikan patin ditentukan oleh pertumbuhan dan jumlah pakan yang diberikan. Lannan et al., (1983) mengatakan bahwa pemberian pakan dalam jumlah kurang akan mengakibatkan kemampuan untuk tumbuh terbatas, sebaliknya pemberian pakan dalam jumlah terlalu banyak dapat mengakibatkan pemborosan. Teknik pemeliharaan ikan yang dapat dilakukan agar pertumbuhan relatif lebih cepat adalah dengan pemberian pakan tambahan yang sesuai dengan proporsi pakan yang sesuai.

Hasil penelitian menunjukan bahwa nilai retensi energi tertinggi terlihat 
pada perlakuan $\mathrm{C}(16 \%)$ dengan nilai rata-rata $30,3 \pm 2,09$ berbeda nyata dengan perlakuan A $(0 \%)$ yaitu $26,9 \pm$ $0,80$ ( $\mathrm{P}<0,05)$, akan tetapi tidak berbeda nyata dengan perlakuan B ( $8 \%)$, D (24\%) dan E (32 \%). Retensi energi tertinggi menunjukan bahwa energi yang terdapat dalam pakan dapat dimanfaatkan secara efisien untuk mensintesis protein tubuh. Suhenda et al., (2004) menyatakan bahwa kebutuhan protein disuplai untuk memenuhi semua kebutuhan energi metabolisme tubuh ikan.

Rata - rata rasio efisiensi protein pada penelitian menunjukkan hasil tidak berbeda nyata, dengan demikian perlakuan substitusi protein limbah biogas terhadap protein bungkil kedelai pada setiap perlakuan terdapat perbedaan variasi yang sedikit. Menurut Jauhari (1990), efisiensi protein akan bervariasi dengan bervariasinya kadar protein dalam pakan dan akan mencapai titik maksimum pada kadar protein tertentu. Pada kualitas protein yang sama, nilai maksimum efisiensi protein juga bervariasi tidak hanya disebabkan oleh jenis ikan yang berbeda, tetapi oleh ukuran ikan tertentu. Dari hasil rata-rata didapatkan hasil terbaik pada perlakuan C (16\%) sebesar $3,6 \mathrm{~g} / \mathrm{g}$.

Hasil penelitian pengamatan selama 28 hari menunjukkan retensi protein memberikan hasil yang tidak berbeda nyata pada setiap perlakuan. Nilai rata - rata retensi protein yang terbaik didapatkan pada perlakuan C (16 \%) sebesar 47,8 \%. Menurut Suhenda et al., (2004) retensi protein cenderung menurun dengan meningkatnya jumlah protein yang dimakan. Selain itu Sumastri, et al., (1993) menyatakan bahwa dalam usaha pembenihan ikan patin, penghematan biaya pakan dapat dicapai melalui efisiensi penggunaan pakan dan pemakaian pakan buatan yang mengandung protein sekitar $35 \%$.

Dalam usaha budidaya, kualitas air merupakan variabel yang mempengaruhi sintasan, perkembangbiakan, pertumbuhan, pengelolaan dan produksi ikan, yang meliputi suhu, oksigen terlarut, $\mathrm{pH}$, serta senyawasenyawa lainnya (Boyd, 1982).

Suhu air media pemeliharaan setiap perlakuan berkisar antara 29,4 $29,6^{\circ} \mathrm{C}$. Menurut Suhenda et al., (2006) bahwa kisaran suhu yang cukup mendukung pertumbuhan benih ikan patin adalah $28-29^{\circ} \mathrm{C}$. Selama penelitian kandungan oksigen terlarut (DO) rata-rata berkisar antara 7,01 - 7,03 ppm, yang masih sangat mendukung untuk reproduksi dan pertumbuhan ikan menurut Boyd (1982).

Nilai $\mathrm{pH}$ air rata - rata selama penelitian berkisar 6,90-6,92. Suhenda et al., (2006) mengatakan bahwa kisaran $\mathrm{pH}$ yang baik untuk pertumbuhan ikan berkisar 7,5 - 8,0. Kandungan amoniak saat penelitian adalah $0,011-0,061 \mathrm{ppm}$, masih berada di bawah kisaran akut sebesar 0,1 - 1,3 ppm (Boyd, 1982).

\section{KESIMPULAN DAN SARAN}

- Limbah biogas kotoran ayam dapat dimanfaatkan sebagai substitusi bungkil kedelai dalam pakan benih ikan patin.

- Substusi protein limbah biogas kotoran ayam terhadap protein bungkil kedelai dalam pakan memberikan pengaruh yang sama terhadap pertumbuhan maupun perbandingan efisiensi pakan benih ikan patin. Nilai rata-rata subsitusi yang terbaik antara protein limbah biogas kotoran ayam terhadap protein bungkil kedelai didapatkan pada perlakuan pakan $\mathrm{C}=16 \%$.

- Subsitusi protein limbah biogas kotoran ayam sebesar $16 \%$ dapat menekan biaya dari penggunaan protein bungkil kedelai yang semakin lama semakin meningkat harganya.

- Dari hasil penelitian disarankan untuk menggunakan substitusi protein limbah biogas kotoran ayam terhadap protein bungkil kedelai sebesar $16 \%$. 


\section{DAFTAR PUSTAKA}

Ahmad, T., L. Sofiarsih, Sutrisno dan Firdaus. 2007. Pemeliharaan Benih Patin Jambal dengan Memanfaatkan Gravitasi dan Posisi Pemasukan Air. Jurnal Penelitian Perikanan Indonesia. $11(5): 85-94$.

Asyari, Z. A dan A. D. Utomo. 1997. Pembesaran Ikan Patin (Pangasius pangasius) dalam Sangkar di Sungai Musi, Sumatera Selatan. Jurnal Penelitian Perikanan Indonesia. 3(2): $83-90$.

Boyd, C. E. 1982. Water Quality Management in Pond Fish Culture. Elsevier Scientific Company. Amsterdam-OxfordNew York. P 301.

Bondari, K. 1984. Comparative Performance of Albino and Normally Pigmented Channel Catfish in Tanks, Cages and Ponds. Aquaculture. 37 : $293-$ 301.

Castell. J. D. and K. Tiews. 1980. Report of the EIFAC, IUNS and ICES Working Group on the Standardization of Metodology in Fish Nutrition Research. Hamburg, Germany. EIFAC Technical Paper, 22 .

Ekawati, A. W. 1992. Optimalisasi Kebutuhan Energi Ransum dengan Dua Level Protein yang Berbeda terhadap Respon Pertumbuhan dan Pemanfaatan Nutrien pada Ikan Nila Merah (Oreochromis sp). Fakultas Perikanan. Universitas Brawijaya. Malang. 50 hal.

Gustiano, R. 2003. Taxonomy and Phylogeny of Pangasiidae Catfish from Asia (Ostariophysi, Siluriformes). Ph.D. Thesis.
Katholieke Universiteit Leuven. $304 \mathrm{p}$.

Hariati, A. M. 1989. Makanan Ikan. NUFFIC/UNIBRAW/LUW/FIS.

Fisheries Project. Penerbit Universitas Brawijaya. Malang. 154.

Jauhari. Z. R. 1990. Kebutuhan Protein dan Asam Amino pada Ikan Teleostei. Fakultas Perikanan. Universitas Brawijaya. Malang 53.

Kadarini. T. 2004. Pengaruh Pemberian Pelet Terapung Komersial Terhadap Pertumbuhan dan Sintasan Patin Jambal (Pangasius djambal). Prosiding Simposium Perhimpunan Ilmu Pemuliaan Indonesia. Hal : $530-535$.

Khans, M. S., K. J. Ang, M. A. Ambak and C.R. Saat. 1993. Optimum Protein Requirement of a Malaysian Freshwater Catfish (Mystus nemurus). Aquaculture. $112: 227-235$.

Lannan, J. E., R. O. Smitherman and G. Ichobanoglaus. 1983. Principles and Practices of Production Aquaculture. Oregon State University. P. $103-115$.

Nasution, Z., E. Dharyati dan Rupawan. 1997. Adopsi Teknologi Budidaya Ikan Patin pada Masyarakat Tani di Desa Mariana, Sumatera Selatan. Jurnal Penelitian Perikanan Indonesia. 3(2) : 35 - 40.

Suhenda, N., E. Tahapari., J. Slembrouck dan Y. Moreau. 2004. Retensi Protein dan Pemanfaatan Energi pada Benih Ikan Patin Jambal (Pangasius djambal) yang Diberi Pakan Berprotein Tinggi. Jurnal Penelitian Perikanan Indonesia. 10(5) : $65-69$. 
Suhenda, N., L. Setijaningsih dan Y. Suryanti. 2005. Pertumbuhan Benih Ikan Patin Jambal (Pangasius djambal) yang Diberi Pakan dengan Kadar Protein Berbeda. Berita Biologi. Jurnal Ilmiah Nasional. 7(4) : 191 - 198.

Suhenda, N., Z. I. Azwar., M. Sulhi dan Y. Moreau. 2006. Evaluasi Pemanfaatan Pakan dengan Sumber Karbohidrat Berbeda untuk Pertumbuhan Benih Ikan Patin Jambal (Pangasius djambal). Jurnal Riset Akuakultur. 1(2) $171-179$.

Sumastri, S., I. P. Kompiang, A. Priyadi dan A. M. Anggawati. 1993. Pengaruh Pakan Buatan Terhadap Performansi Produksi Benih Pangasius sutchi. Buletin Penelitian Perikanan. Edisi Khusus. $5: 145-148$.

Tahapari, E., D. Ariyanto dan B. Gunadi. 2007. Optimasi Pemberian Pakan Buatan pada Pendederan Ikan Patin di Kolam yang di Pupuk. Seminar Nasional Tahunan IV Hasil Penelitian Perikanan dan Kelautan. Pembenihan dan Pakan Ikan $(\mathrm{PP}-15): 7$.
Utami, R., E. Tahapari dan N. Suhenda. 2003. Pengaruh Jumlah Pemberian Pakan Alami (Moina sp) dan Lama (Hari) Pemberiannya Terhadap Pertumbuhan dan Sintasan Benih Ikan Patin Jambal (Pangasius djambal).

Viola, S. and U. Rappaport. 1979. The Extra Calorie Effect of Oil in Nutrition of Carp. Bamidgeh. $31(3): 51-69$.

Yunus, M. 1995. Teknik Membuat dan Memanfaatkan Unit Gas Bio. Gajah Mada University Press. Yogyakarta. 